\title{
PERENCANAAN SISTEM PENYEDIAAN AIR MINUM DALAM RANGKA PENINGKATAN PELAYANAN DI WILAYAH IKK LEUWIMUNDING, PALASAH, SUMBERJAYA KABUPATEN MAJALENGKA
}

\author{
Evi Afiatun*, Sri Wahyuni, Riki Dwi Taruna \\ Program Studi Teknik Lingkungan, Universitas Pasundan
}

\begin{abstract}
Abstrak
Air merupakan kebutuhan pokok yang paling mendasar bagi kehidupan manusia. Peningkatan pertumbuhan penduduk yang meningkat menyebabkan kebutuhan air yang meningkat,sehingga terjadi juga di Kabupaten Majalengkaterutama IKK Leuwimunding, Palasah, Sumberjaya.Berdasarkan penelaahan atas kualitas air baku,Peraturan Pemerintah No. 82 tahun 2001, tentang Pengelolaan Kualitas Air dan Pengendalian Pencemaran Air, hasil pemeriksaan di laboratorium menjelaskan bahwa semua parameter memenuhi standar air baku, kecuali parameter E.coli sehingga membutuhkan proses desinfeksi. Oleh karena itu, pengolahan air minum yang lengkap tidak diperlukan.Dari hasil perhitunganproyeksi jumlah penduduk untuk 10 tahun perencanaanhingga tahun 2025, airbaku yang diperlukan sebesar 245 1/dtk.Sedangkan debit sumber mata air memiliki kapasitas sebesar 450 1/dtk. Unit yang akan digunakan yaitu bangunan penangkap mata air, bangunan penampung, desinfeksi dan reservoir. Perhitungan sistem perpipaan air minum menggunakansoftware EPANET 2.0. Dengan investasi rencana anggaran biaya sebesar Rp. 25.640.136.000,00.
\end{abstract}

Kata kunci: Epanet 2.0,Kualitas Air Baku, Kebutuhan Air, Sistem Penyediaan Air Minum

\section{Pendahuluan}

Kabupaten Majalengka merupakan kota kabupaten yang sedang berkembang sesuai dengan pertumbuhan penduduknya, sehingga memerlukan penambahan dan pengembangan sarana serta prasarana yang dapat menunjang segala aktivitas penduduknya. Salah satu prasarana kota yang paling utama adalah sistem penyediaan air minum. Di Indonesia standar air minum ditetapkan oleh Peraturan Mentri Kesehatan RI (Nomor.492/MENKES/PER/IV/

\footnotetext{
${ }^{*}$ Penulis Korespondensi:

E-mail: eviafiatun@unpas.ac.id

Diterima pertama kali: 13 Desember 2017

Direvisi : 5 Februari 2018

Disetujui untuk publikasi: 7 Februari 2018
}

2010) tentang "Persyaratan Kualitas Air Minum".

Melihat fungsi Ibu Kota Kecamatan (IKK) Leuwimunding, Sumberjaya dan Palasah serta potensi yang cukup besar untuk pengembangan sistem penyediaan air minum dengan sistem perpipaan di proyeksikan pada akhir Tahun 2025. Sedangkan saat ini IKK Leuwimunding, Sumberjaya dan Palasah belum mempunyai sistem perpipaan.

Oleh sebab itu diperlukannya upaya memenuhi kebutuhan akan air minum untuk masyarakat di Kecamatan Leuwimunding, Sumberjaya dan Palasah memerlukan pembangunan sarana dan prasarana air minum tersebut. Pelayanan untuk ketiga Kecamatan tersebut direncanakan dengan sistem gravitasi dari Mata Air Cirumput yang 
berada di Desa Teja Kecamatan Rajagaluh yang mempunyai kapasitas $\pm 450 \mathrm{l} / \mathrm{det}$, memerlukan pembangunan Broncaptering, Bak Penampung, Reservoar dan jaringan distribusi.

Dari pertimbangan tersebut maka diperlukan suatu kegiatan yang terpadu dan terencana dari mulai tahap perencanaan, pelaksanaan, sampai dengan operasi dan pemeliharaan. Perencanaan yang baik diperlukan agar tepat sasaran dalam pemecahan masalah dan menjaga efisiensi dalam tindakan pada tahapan-tahapan selanjutnya.

Tujuan dari kajian ini adalah merencanakan sistem penyediaan air minum dalam rangka peningkatan pelayanan untuk tiga kecamatan di Kabupaten Majalengka selama 10 tahun perencanaan.

\section{Metodologi}

\section{Lokasi Perencanaan}

Daerah studi perencanaan sistem penyediaan air minum adalah wilayah Leuwimunding, Palasah dan Sumberjaya. Masyarakat setempat memerlukan akan kebutuhan air bersih untuk mengatasi kesulitan air yang terjadi, sehingga memanfaatkan air sumur akan kebutuhan seharihari masih kurang baik, karena air sumur mengandung kadar besi dan mangan yang tinggi.

\section{Pemilihan Sumber Air Baku}

Sumber air baku yang dipilih harus bebas dari pencemaran baik pada saat ini maupun di masa yang akan datang. Pada perencanaan sistem penyediaan air minum di IKK Leuwimunding, Palasah dan Sumberjaya air baku akan diambil dari Mata Air Cirumput yang terletak di Desa Teja Kecamatan Rajagaluh Kabupaten Majalengka. Dasar pemilihan Mata Air Cirumput menjadi sumber air baku dengan mempertimbangkan jarak dan kualitas mata air cukup baik.

Ketersediaan air atau debit air baku dari sumber air yang akan dimanfaatkan harus dapat memenuhi kebutuhan air suatu periode perencanaan tertentu. Dari data yang di peroleh dari PDAM Tirta Dharma Kabupaten Majalengka, adapun debit dari sumber air baku Cirumput 450 L/detik. Sedangkan pada musim kemarau untuk mata air Cirumput mencapi debit minimum 370 L/detik. Sebagian sumber air baku dari mata air untuk saat ini sekitar 20\% digunakan untuk irigasi pertanian dan untuk sisanya belum dimanfaatkan.

\section{Perhitungan Kebutuhan Air}

Salah satu hal yang paling penting untuk merencanakan suatu kebutuhan air minum sebelum perencanaan dimulai harus mengetahui terlebih dahulu mengenai volume dan debit air yang akan dialirkan serta berkaitan dengan jumlah penduduk dalam priode perencanaan. Dengan memproyeksikan jumlah penduduk berdasarkan perkembangan sosial dan ekonomi di daerah perencanaan, maka akan diketahui perkiraan kebutuhan air dimasa mendatang. Metode proyeksi penduduk yang digunakan adalah Aritmetika, Geometri, dan Least Square.

\section{Penentuan Jalur Pipa}

Sistem distribusi ialah penyaluran air minum dari reservoir ke daerah perencanaan dan merupakan sistem yang paling penting dalam suatu penyediaan air minum sampai kepada konsumen dengan kualitas baik. Beberapa hal penting yang perlu di perhatikan dalam sistem distribusi adalah (Yosefa \& Indarjanto, 2017):

- Kualitas air minum yang sampai pada konsumen harus memenuhi persyaratan peraturan pemerintah.

- Ketersediaan air minum harus mencukupi setiap saat pada konsumen.

- Menggunakan pipa dan perlengkapannya berkualitas tinggi untuk mencegah terjadinya kebocoran atau kerusakan yang mungkin terjadi.

- Tekanan dalam aliran pipa harus dapat menjangkau daerah pelayanan terjauh, 
sehingga dapat terlayani dengan maksimal.

\section{Perhitungan Hidrolis Jalur Perpipaan}

Perhitungan hidrolis perpipaan air minum dihitung menggunakan sofware EPANET versi 2.0 yang menggunakan rumus Hazen William untuk perhitungan matematisnya (Rossman, 2000). Data-data yang digunakan untuk menjalankan program epanet yaitu panjang pipa, debit, diameter pipa dan ketinggian tanah. Hasil dari program tersebut adalah kecepatan aliran, arah aliran dan sisa tekan.

\section{Daerah Rencana Pelayanan}

Dalam rencanaan pelayanan ini menggunakan perpipaan sistem Loop atau Perpipaan Lingkaran. Sistem jaringan perpipaan melingkar digunakan untuk daerah pelayanan dengan karakteristikbentuk dan perluasannya menyebar ke seluruh arah.Jaringan jalannya berhubungan satu dengan yang lainnya dan Elevasi tanahnya relatif datar. Sehingga dianggap mempermudah jaringan untuk menentukan titik sadap. Pendistribusian debit air minum di daerah pelayanan pada prinsipnya harus dapat melayani daerah pelayanan, karena besarnya debit pelayanan berbeda dan tergantung pada beban pelayanan.

\section{Hasil dan Pembahasan}

\section{Proyeksi Timbulan Sampah}

Tabel 1 adalah hasil perhitungan nilai koefisien korelasi dan standar deviasi dari tiga metode yang digunakan untuk proyeksi penduduk.

Tabel 1. Nilai Koefisien Korelasi (R) dan Standar Deviasi (SD) Dari Ketiga Metode

\begin{tabular}{lll}
\hline Metode & R & SD \\
\hline Aritmatika & 0,991 & 977 \\
\hline Geometri & 0,992 & 901 \\
\hline Least Square & 0,991 & 540 \\
\hline
\end{tabular}

Pada Tabel 1 dapat terlihat bahwa yang paling memenuhi syarat adalah metode Least Square, maka metode ini merupakan metode terpilih yang akan digunakan sebagai metode proyeksi penduduk untuk perencanaan sistem penyediaan air minum. Proyeksi penduduk dengan menggunakan metode least square dari tahun 2015 sampai dengan 2025 dapat dilihat pada Tabel 2.

Tabel 2. Proyeksi Penduduk Dengan Metode Least Square

\begin{tabular}{cc}
\hline Tahun & Least Square \\
\hline 2015 & 162479 \\
\hline 2016 & 163734 \\
\hline 2017 & 164990 \\
\hline 2018 & 166245 \\
\hline 2019 & 167501 \\
\hline 2020 & 168756 \\
\hline 2021 & 170012 \\
\hline 2022 & 171267 \\
\hline 2023 & 172523 \\
\hline 2024 & 173778 \\
\hline 2025 & 175034 \\
\hline
\end{tabular}

\section{Kebutuhan Air Domestik}

Sebelum melakukan perencanaan dan menganalisa kebutuhan air untuk pelayanan air minum IKK Leuwimunding, Palasah dan Sumberjaya 10 tahun perencanaan yang akan datang, diperoleh penduduk berdasarkan presentase pertumbuhan penduduk $1,008 \%$ per tahun berdasarkan data dari BPS Kabupaten Majalengka.

Berdasarkan hasil perhitungan proyeksi pertumbuhan dan proyeksi kebutuhan air fasilitas domestik dan non domestik diketahui bahwa kebutuhan air untuk sampai akhir tahun perencanaan dapat dilihat pada Tabel 3. 
Tabel 3. Kebutuhan Air Total

\begin{tabular}{lcc}
\hline \multirow{1}{*}{\multicolumn{1}{c}{ Fasilitas }} & \multicolumn{2}{c}{$\begin{array}{c}\text { Kebutuhan Air } \\
\text { (L/dtk) }\end{array}$} \\
\cline { 2 - 3 } & $\mathbf{2 0 1 5}$ & $\mathbf{2 0 2 5}$ \\
\hline Debit Domestik & 70,408 & 202,261 \\
\hline Debit Non & & \\
Domestik & 17,003 & 18,673 \\
\hline Debit Fire Hydrant & 7,041 & 20,226 \\
\hline $\begin{array}{l}\text { Debit \% } \\
\text { Kehilangan Air }\end{array}$ & 1,408 & 4,045 \\
\hline Debit total & 96 & 245 \\
\hline Jam Maksimum & 144 & 367 \\
\hline Hari Maksimum & 115 & 294 \\
\hline
\end{tabular}

\section{Rencana Jaringan Distribusi}

Pada perencanaan sistem jaringan distribusi air minum di IKK Leuwimunding, Palasah dan Sumberjaya dapat dilihat pada gambar 3 simulasi EPANET 2.0.sebagai alat bantu simulasi sistem penyediaan air minum bertujuan untuk mendapatkan nilai tekanan, aliran maksimal dan minimal yang terjadi pada wilayah perencanaan (dengan pola loopmaupun kombinasi). Simulasi jaringan perpipaan pada sistem distribusi untuk tahun 2025 terlihat seperti pada Gambar 2.

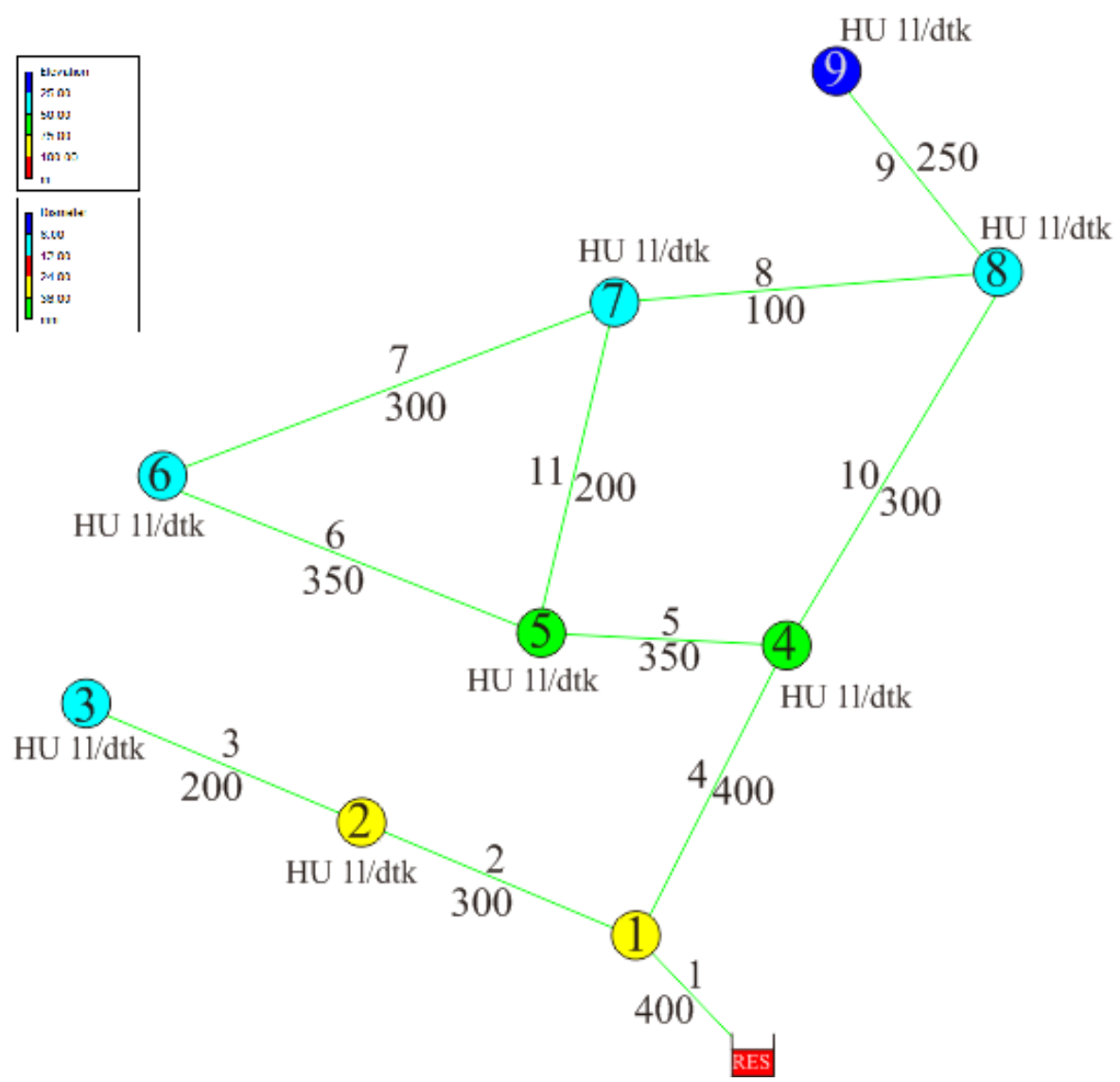

Gambar 2. Jaringan pipa distribusi hasil simulasi Epanet

\section{Pembagian Debit Tiap Titik Sadap}

Untuk pembagian debit setiap titik sadap IKK Leuwimunding, Palasah, Sumberjaya direncanakan dengan tiga titik sadap untuk setiap Kecamatannya. Kecamatan Sumberjaya mendapatkan aliran pelayanan air yang paling besar yaitu $51 \mathrm{~L} / \mathrm{dtk}$, Kecamatan Leuwimunding mendapatkan debit sebesar 40,6 L/dtk, sedangkan Kecamatan Palasah memperoleh debit sebesar $31 \mathrm{~L} / \mathrm{dtk}$. Untuk pembagian debit titik sadap dapat dilihat pada Tabel 4 berikut. 
Tabel 4. Kebutuhan Air Setiap Blok dari Reservoir

\begin{tabular}{|c|c|c|c|c|}
\hline Kecamatan & $\begin{array}{c}\text { Total } \\
\text { Kebutuhan } \\
\text { Air (L/dtk) }\end{array}$ & $\begin{array}{l}\text { Pelayanan } \\
\text { Node }\end{array}$ & $\begin{array}{c}\text { Total } \\
\text { Kebutuhan } \\
\text { Air (L/dtk) } \\
\text { Node }\end{array}$ & $\begin{array}{l}\text { Elevasi } \\
\text { (mdpl) }\end{array}$ \\
\hline \multirow{3}{*}{ Leuwimunding } & \multirow{3}{*}{122} & 1 & 40,6 & 99 \\
\hline & & 4 & 40,6 & 50 \\
\hline & & 5 & 40,6 & 50 \\
\hline \multirow{3}{*}{ Palasah } & \multirow{3}{*}{94} & 2 & 31 & 83 \\
\hline & & 3 & 31 & 52 \\
\hline & & 6 & 31 & 48 \\
\hline \multirow{3}{*}{ Sumberjaya } & \multirow{3}{*}{153} & 7 & 51 & 28 \\
\hline & & 8 & 51 & 25 \\
\hline & & 9 & 51 & 22 \\
\hline
\end{tabular}

\section{Perhitungan Sistem Jaringan Distribusi}

Hal yang perlu diperhatikan dalam perhitungan sistem jaringan distribusi ini adalah sisa tekan, karena sisa tekan ini menentukan sampai tidaknya air pada konsumen. Adapun hasil perhitungan dapat dilihat pada Tabel 5 dan Tabel 6 berikut.

Tabel 5. Perhitungan Network Nodes

\begin{tabular}{lcccc}
\hline $\begin{array}{c}\text { Node } \\
\text { ID }\end{array}$ & $\begin{array}{c}\text { Elevation } \\
(\mathbf{m})\end{array}$ & $\begin{array}{c}\text { Demand } \\
(\mathbf{L P S})\end{array}$ & $\begin{array}{c}\text { Head } \\
(\mathbf{m})\end{array}$ & $\begin{array}{c}\text { Pressure } \\
(\mathbf{m})\end{array}$ \\
\hline Junc 1 & 99 & 40.60 & 118.01 & 19.01 \\
\hline Junc 2 & 83 & 31.00 & 105.13 & 22.13 \\
\hline Junc 3 & 52 & 31.00 & 92.67 & 40.67 \\
\hline Junc 4 & 50 & 40.60 & 73.84 & 23.84 \\
\hline Junc 5 & 50 & 40.60 & 65.12 & 15.12 \\
\hline Junc 6 & 48 & 31.00 & 60.55 & 12.55 \\
\hline Junc 7 & 28 & 51.00 & 55.49 & 27.49 \\
\hline Junc 8 & 25 & 51.00 & 50.95 & 22.95 \\
\hline Junc 9 & 22 & 51.00 & 41.09 & 19.09 \\
\hline Reserv & 141 & -367.80 & 141.00 & 0.00 \\
\hline
\end{tabular}

Tabel 6. Perhitungan Network Link

\begin{tabular}{cccccc}
\hline $\begin{array}{c}\text { Link } \\
\text { ID }\end{array}$ & $\begin{array}{c}\text { Length } \\
(\mathrm{m})\end{array}$ & $\begin{array}{c}\text { Diameter } \\
(\mathrm{mm})\end{array}$ & $\begin{array}{c}\text { Flow } \\
(\text { LPS })\end{array}$ & $\begin{array}{c}\text { Velocity } \\
(\mathrm{m} / \mathrm{s})\end{array}$ & Headloss \\
\hline Pipa 1 & 1494 & 400 & 367.00 & 2.93 & 15.39 \\
\hline Pipa 2 & 5570 & 300 & 62.00 & 0.88 & 2.31 \\
\hline Pipa 3 & 2700 & 200 & 31.00 & 0.99 & 4.61 \\
\hline Pipa 4 & 5258 & 400 & 265.20 & 2.11 & 8.40 \\
\hline Pipa 5 & 2112 & 350 & 125.14 & 1.32 & 4.13 \\
\hline Pipa 6 & 3865 & 350 & 50.45 & 0.67 & 1.18 \\
\hline
\end{tabular}

\begin{tabular}{lccccc}
\hline Pipa 7 & 6738 & 300 & 19.45 & 0.48 & 0.75 \\
\hline Pipa 8 & 1122 & 100 & 2.54 & 0.59 & 4.05 \\
\hline Pipa 9 & 2520 & 250 & 51.00 & 1.04 & 3.91 \\
\hline Pipa 10 & 4296 & 300 & 99.46 & 1.38 & 5.33 \\
\hline Pipa 11 & 3966 & 200 & 34.09 & 0.70 & 2.43 \\
\hline
\end{tabular}

\section{Rencana Anggaran Biaya}

Harga satuan barang atau pekerjaan diperoleh dan dikembangkan dari beberapa sumber diantaranya:

- Harga satuan barang dan upah yang berlaku dilokasi proyek.

- Dari pabrik agen atau pemasok barang.

- Satuan harga yang digunakan pada proyek-proyek yang sedang berjalan saat ini.

- Daftar harga yang digunakan oleh Dirjen Cipta Karya, Dinas Pemukiman dan Perumahan Propinsi Jawa Barat terutama yang telah diterapkan oleh PDAM Majalengka.

Harga satuan diajukan sudah mencakup harga bahan atau peralatan, upah buruh dilokasi proyek, biaya pengiriman barang, keuntungan pabrik atau pemasok dan lain sebagainya. Jumlah keseluruhan biaya yang dibutuhkan dalam perencanaan unit bangunan air minum dapat dilihat pada Tabel 7. 
Tabel 7. Rekapitulasi Anggaran Biaya

\begin{tabular}{|c|c|c|}
\hline No. & URAIAN PEKERJAAN & $\begin{array}{c}\text { JUMLAH HARGA } \\
\text { (Rp) }\end{array}$ \\
\hline 1. & PEKERJAAN PERSIAPAN & 20.950 .000 \\
\hline 2. & PEKERJAAN BANGUNAN PENANGKAP MA & 654.472 .209 \\
\hline 3. & PEKERJAAN PADA JALUR TRANMISI & 7.615 .699 .000 \\
\hline 4. & PEMBANGUNAN PEMBUBUH KIMIA & 39.797 .830 \\
\hline 5. & PEKERJAAN BANGUNAN RESERVOIR & 1.918.287.040 \\
\hline 6. & PEKERJAAN PADA JALUR DISTRIBUSI & 10.940 .989 .125 \\
\hline 7. & SUB TOTAL & 21.190 .195 .204 \\
\hline 8. & BIAYA TAK TERDUGA $(10 \% \times$ Biaya Sub Total $)$ & 2.119 .019 .520 \\
\hline 9. & PPN $(10 \% \times$ Sub Total $)$ & 2.330 .921 .472 \\
\hline 10. & TOTAL & 25.640 .136 .196 \\
\hline \multicolumn{2}{|c|}{ PEMBULATAN } & 25.640 .136 .000 \\
\hline
\end{tabular}

\section{Kesimpulan}

Berdasarkan pembahasan pada bagian sebelumnya, maka dapat diperoleh kesimpulan dari artikel ini yang diantaranya adalah seperti berikut:

- Debit pengolahan untuk tahun perencanaan 2015 sampai 2025 adalah sebesar 245 L/dtk.

- Metode proyeksi yang digunakan adalah metode Least Square

- Berdasarkan kondisi geografi dan topografi letak reservoir beradapada ketinggian 141 mdpl, sehingga sistem penyediaan air bersih dapat menggunakan sistem gravitasi.
- Berdasarkan hasil perhitungan simulasi epanet 2.0 sisa tekan pada ujung pipa sebesar $19,09 \mathrm{~m}$

\section{Daftar Pustaka}

Rossman, L. A. (2000). EPANET 2.0 Users Manual. Cincinnati: Environment Protection Agency.

Yosefa, F., \& Indarjanto, H. (2017). Analisis Perencanaan dan Pengembangan Jaringan Distribusi Air Bersih di PDAM Tulungagung. JURNAL TEKNIK ITS, Vol. 6, No. 1: D25-D-29. 